artigo $]$

[ IZABEL HADDAD MARQUES MASSARA ]

Mestre e doutora em Psicanálise pela Universidade Federal de Minas Gerais (UFMG). É psicanalista e tem especial interesse em aplicações dessa teoria ao campo da cultura e da arte.

E-mail: izabelhaddad@hotmail.com

\title{
Uma mulher no rastro da seda ${ }^{1}$
}

\section{The woman on the track of the silk}

[resumo] 0 presente artigo apresenta a história de uma costureira parisiense e de sua curiosa paixão por sedas no ano em que o Primeiro Salão de Moda de Paris acontecia, alimentado pelos ares frutíferos da Belle Époque. Entre os lançamentos de moda estava o ícone dos últimos tempos: o vestido de seda. Foi nesse cenário que Marie Benjamin começou a furtar tecidos. Havia sido presa 26 vezes por pegar as sedas nas bancas dos magazines de tecidos da cidade. Além do roubo, masturbava-se compulsivamente com os retalhos em plena loja. Era presa e conduzida aos manicômios da cidade, onde conheceu o médico Gaetan Gatian de Clérambault, um psiquiatra excêntrico que amava, além da medicina, os tecidos e drapeados árabes. 0 encontro improvável entre esses dois personagens é uma história real com nuances dos contos fantásticos do século XIX.

\section{palavras-chave}

moda; seda, vestido, feminilidade;

cleptomania.

[abstract] This article presents the story of Marie Benjamin, a Parisian dressmaker and her curious passion for silk. The story takes place during the First Fashion Salon of Paris, inside the Belle Époque's atmosphere. The starlight of that salon was the silk dress, and it would become an icon for the coming years. Marie Benjamin was somebody that developed the pathological behavior of stealing tissues, and was arrested twenty six times for that. She used to go to the stores, steal big pieces of silk and use it to masturbate compulsively, even while she was inside that stores. After being arrested, she was conducted to the district's sanatoria, where she met Dr. Clérambault. This man was an eccentric psychiatrist who was not only passionate for his clinical work, but also for dressing, tissues and Arabic drapery. This article intends to present and discuss some aspects of the encounter between these two characters.

[keywords] fashion; silk; dress; feminine; cleptomania. 
Paris, virada do século, Primeiro Salão de Moda da Europa, o vestido de seda acaba de ser lançado e as mulheres acreditavam que ele era a encarnação da feminilidade que lhes havia sido furtada anos a fio pelos sufocantes espartilhos de osso. Em meio ao burburinho da nova coleção de modelos esvoaçantes apelidados de La vague (a onda), uma costureirinha parisiense, Marie Benjamin ${ }^{2}$, adentra em um importante magazine de tecidos com uma tesoura em punho e recorta, sem muito cuidado, uma longa nesga de seda vermelha, com a destreza de quem havia sido acostumada a costurar vestidos para as mulheres da alta sociedade parisiense. Pouco tempo depois, com um ar de triunfo e já com o pedaço de tecido nas mãos, ela se recolhia num canto qualquer da loja, onde pudesse ser entrevista, e, sem pudor, de forma a exibir-se ao olhar de algum espectador mais atento, entregava-se à masturbação, lançando mão do corte da seda que acabara de tomar da banca de tecidos mais próxima. Depois de experimentar um gozo arrebatador, como ela mesma descrevia, era surpreendida pela polícia da cidade. Os guardas e quem mais estivesse por perto se deparavam com uma cena protagonizada por dois personagens: Marie e a seda. 0 rastro de tecido recortado pelo chão se estendia da banca de tecidos até o meio das pernas da moça.

0 trecho que acabamos de descrever apresenta o cenário da primeira cena do filme 0 grito da seda $a^{3}$, do diretor Yvon Marciano, que recriou cinematograficamente a história verídica da paciente Marie Benjamin e seu médico, 0 alienista francês Gaetan Gatian de Clérambault. 0 longa-metragem é uma ficção elaborada em torno de um encontro real entre essa costureira cleptomaníaca, apaixonada por tecidos, que desenvolvera um sintoma recorrente de se masturbar com pedaços de seda desde os 7 anos de idade, e seu médico, um psiquiatra que, entre outras excentricidades, cultivava o fascínio pelo estudo dos drapeados árabes e também pelos tecidos.

Foi Clérambault, o médico, em seu artigo "A paixão erótica das mulheres pelos tecidos", que cunhou a metáfora "o grito da seda", utilizada como título do filme. Nele, o psiquiatra fala das sensiveis observações feitas pela paciente Marie sobre os barulhos muito particulares emitidos pelo esfregar da seda na epiderme do corpo. Ela descreveu como uma espécie de gritos os estalidos que, provindos dos movimentos da seda, pareciam eletrizá-la. Para a paciente, a seda era fina, fresca e firme, como um corpo a deflagrar sons singulares e sedutores que a atraíam sobremaneira, desencadeando um gozo sexual.

Na ocasião da irrupção do sintoma cleptomaníaco dessa costureira, esse tipo de tecido não era somente o objeto de eleição de suas paixões, mas a coqueluche dos estilistas e das parisienses da época. A seda era não só o ícone de leveza e liberdade, mas a insígnia maior de feminilidade para as mulheres daquele período. 0 século XIX havia sido deixado para trás e o século XX acabara de chegar trazendo mudanças radicais, inclusive o advento da Moda na França. Nesse cenário, uma femme comme il faut ${ }^{5}$, expressão que designaria, como descreveu Honoré de Balzac (2006), uma típica e elegante senhora da sociedade parisiense, precisaria, a partir de então, de luvas, meias e vestidos de seda. Nenhum outro artigo de luxo era mais importante na toalete das francesas do que esse fio sedoso que acabara de chegar em Paris, vindo do Oriente.

Não por acaso, como se vê, imersa nesse contexto, a doença histérica de Marie irrompeu e foi assistida com atenção pelo psiquiatra em meio à curiosa paixão por tecidos nutrida por ambos, médico e paciente. A relação afetiva de Clérambault pela tecelagem e o desregramento de Marie talvez já existissem há algum tempo, entretanto, naquele momento, foram animados e alimentados silenciosamente pelo discurso de uma época. A virada do século produziu uma série de transformações no campo da arte, da ciência e mesmo da psiquiatria, campo de saber no qual Clérambault colhia os preceitos de sua clínica médica.

Voltando à cena inicial do filme de Yvon Marciano: quando a personagem Marie Benjamin entra em importante magazine de tecidos de Paris, antecipa-se para o espectador o motivo que a levou até o Dr. Clérambault. Na vida real, o encontro se dá no ano de 1905, após a costureira ser levada, pelos guardas que faziam vigília nas ruas 
de Paris, até a delegacia de polícia da cidade, por causa do furto de sedas numa das lojas de tecidos. No subsolo dessa delegacia, encontrava-se a enfermaria de alienados onde os supostos loucos eram assistidos pelos cuidados do jovem médico que exercia sua clínica por ali. Clérambault dividia seu tempo entre as aulas que ministrava na Faculdade de Belas Artes e a coordenação da enfermaria de alienados.

Esse encontro poderia nunca ter acontecido, mas as particularidades da vida dessas duas figuras os levaram a um mesmo lugar e a uma mesma paixão. Ela, uma "costureira de corte simples ${ }^{6 "}$, como eram chamadas as mulheres que confeccionavam em suas próprias casas roupas para as madames da sociedade. Ele, um médico psiquiatra do famoso grupo dos "franceses do entreguerras" ${ }^{7 "}$ que deveria restringir seu trabalho a observar os sintomas e sinais dos doentes psiquiátricos encontrados nas ruas da Cidade-Luz. Assim como seus outros colegas de profissão, observando apenas e anotando no prontuário o diagnóstico clínico preciso, estaria contribuindo com a corrente construção da nosografia psiquiátrica da época.

Logo, se a vida desses dois personagens tivesse transcorrido como "mandava 0 figurino", Gaetan Gatian de Clérambault, como a maioria dos psiquiatras, teria apenas preenchido algumas centenas de prontuários médicos que estariam hoje esquecidos nos arquivos de literatura psiquiátrica de sua época, e Marie permaneceria em casa costurando vestidos da estação para as parisienses mais afortunadas. Entretanto, para além do famoso encontro entre uma histérica e seu psiquiatra, a história desses dois franceses se encontra intimamente enlaçada por um desejo compartilhado: ambos alimentavam, em segredo, uma curiosa paixão pelo mesmo objeto: os tecidos. Seguiremos pelo rastro deixado pela inauguração do primeiro Salão de Moda de Paris no ano de 1900, para descrever como o leitmotif dessa época fez surgir a seda como 0 objeto de desejo mais cobiçado dos tempos.

\section{O Salão de Moda de Paris}

No mesmo momento em que os loucos, as prostitutas e os desviados eram presos pela polícia parisiense, e as histéricas, como Marie, eram enclausuradas pela psiquiatria na periferia da cidade, nos hospícios, numa estratégia de saneamento social, Paris fervilhava como o epicentro da Moda. A alta-costura francesa experimentava, nos primeiros anos do século $X X$, um de seus triunfantes momentos, ao entrar em cena como uma das vedetes da Exposição Mundial de Moda ${ }^{8}$. No ano de 1900, 0 Pavillon de l'Élegance, da primeira feira de Moda de Paris, que revelou novos modelos de vestidos e uma variedade de tecidos leves e flexíveis, anunciava de forma inovadora a maneira como as mulheres iriam se vestir em Paris. Não fosse parte de um contexto que traduziu o espírito de toda uma época, esse evento seria somente um episódio importante para o advento da Moda no Ocidente.

Nesse palco, Marie Benjamin teceria seu sintoma de devoção pela seda, e Clérambault se desdobraria para descrever o caso de quatro pacientes arrebatadas pelo mesmo sintoma associado às qualidades táteis e sensoriais do tecido da seda. 0 início do século $X X$ tingiu com as nuances próprias daquele tempo o objeto de eleição de uma paixão compartilhada. 0 fato de ambos nutrirem um apreço semelhante pelos tecidos os aproximou de forma inegável, já que era improvável que uma costureira que podia comprar sedas preferia roubá-las, e que um médico, que participava ativamente da construção da nosografia psiquiátrica, desviasse seu interesse em suas horas vagas para os tecidos e à arquitetura das tecelagens.

Compondo o cenário desse encontro, Paris foi animada por uma dicotomia entre um passado vitoriano, cheio de pudores, e um presente fervilhante, tomado pela arte impressionista. A virada do século trouxe consigo um divisor de águas em vários setores da vida social. Com isso, previu-se que a Moda, fenômeno em que sempre se refletiam as novas formas de viver e pensar, iria acompanhar a flexibilidade que se viu naqueles anos. Os novos tecidos e modelos de roupas que vestiriam principalmente as mulheres dessa época, influenciados pelos artistas daquele tempo e pelo modernismo que reinava na Europa, destacaram-se por acabar com a moda dos bustos curvos e dos derrières salientes e tornar gradativamente o corpo feminino mais livre. 
0 corpo da mulher até então era apresentado pela fantasia dos estilistas de Moda contornado como um chumaço de tecido brocado e apertado em forma de uma ampulheta: exuberante na parte do busto e nas pernas. Exibiam colarinhos estreitos e compridos, com pontas fixas, exigindo uma posição correta da cabeça, sobre a qual adereços exuberantes pesavam como chumbo. 0 corpo de toda a roupa era estruturado sobre estruturas feitas de escamas de peixe, e as mangas eram abalonadas nos ombros, presas no cotovelo, e justas até o pulso. Para se despir, uma mulher precisava se desvencilhar de muitas camadas de tecidos, duros e armados. Tarefa árdua, comparável à tomada de uma fortaleza, diria um estilista francês ${ }^{9}$.

Até que tivesse início o processo de liberação do corpo feminino através das tendências da Moda, fato que aconteceu no início do século retrasado, os vestidos seguiam uma única linha: eram como uma prisão. As mulheres, quando vestidas a rigor, assim como as supostas loucas assistidas pelo olhar austero e atento dos médicos nas sessões clínicas de apresentação de pacientes histéricas nos hospitais psiquiátricos, estariam encarceradas em suas camisas de força. Esboçou-se, a partir de então, um vestido de linhas simples e estreitas, cujo tecido, leve e macio, caía dos ombros até os pés. 0 novo corte foi chamado de La vague $^{10}$ (A onda), pois deslizava em torno do corpo suavemente. 0 vestido da reforma ${ }^{11}$, imortal e etéreo, apenas contornava o que a ele se sobrepunha. Assim, sob a leveza da seda se reconfigurava uma mulher mais livre, substituindo a figura de espartilho e pó de arroz dos anos que passaram.

A seda foi o material utilizado pelos estilistas no primeiro vestido que libertou o corpo feminino das amarras da fantasia masculina, encarnada pelo espartilho. Os tecidos leves agregaram qualidades como a flexibilidade, a fineza e o frescor, que eram, por isso mesmo, um símbolo de libertação para as mulheres daquela época. Elas emprestariam pela primeira vez o próprio corpo como "cabides-vivos" para as criações estilísticas dos costureiros e alfaiates da Haute Couture ${ }^{12}$. Entretanto, as costureiras como Marie só podiam trabalhar em suas próprias casas na confecção de vestidos simples, pois o prestígio e o luxo das invenções de Moda estavam reservados somente aos homens, os couturiers ${ }^{13}$.

Foi em meio aos eventos do Salão de Moda de Paris que floresceu o sintoma cleptomaníaco que Marie levou a público nas lojas de tecidos. Foi também nesse exato momento que Clérambault começou a escrever seu texto sobre $A$ paixão erótica da mulher pelos tecidos (1908). Tempos depois, ele se revezaria entre o cargo de médico-chefe da enfermaria de alienado e professor da disciplina sobre os drapeados árabes na escola de Belas Artes. 0 médico iria se dividir entre o dever de produzir a crescente nosografia das espécies psíquicas que iriam compor a nova ciência psiquiátrica da época e seu desejo pelo estudo das também espécies de tecidos.

\section{Clérambault: médico e artista plástico}

Gaetan Gatian de Clérambault foi descrito no livro Os fundamentos da clínica: história e estrutura do saber psiquiátrico, de Paul Bercherie (1989), como um homem de estilo lapidar e encantador, cuja concisão e eficácia produziram um verdadeiro talento de observação analítica. 0 jovem médico era considerado perspicaz e carismático. Além disso, ao mesmo tempo em que exerceu um fascínio em seus contemporâneos, despertou paixões hostis no grupo de psiquiatras franceses, devido à sua maneira de conduzir seus estudos e sua própria vida (BERCHERIE, 1989).

Como médico, ficou famoso entre seus pares por descrever os pacientes que atendia com a "minúcia de um colecionador de espécies raras ${ }^{14 "}$. Considerado um excelente clínico, fazia jus aos preceitos da clínica psiquiátrica de sua época: observador atento e minucioso, listava com destreza os sintomas psicopatológicos e dissecava, no tempo de uma breve anamnese, a personalidade psíquica de seus pacientes. Descreveu e descobriu a síndrome do automatismo mental ${ }^{15}$ - fenômeno ainda hoje reconhecido como peculiar a determinados estados psicóticos - e a erotomania ${ }^{16}$, sintoma que ficou conhecido como "Síndrome de Clérambault".

Dedicava-se aos pacientes nomeados de desviantes e amorais pelo discurso psiquiátrico de sua época. Vertia uma atração particular por toda espécie de sujeitos que apresentavam certo desregramento afetivo, um tipo de excesso diagnosticado de degenerescência mental. Essa predileção pelo estudo dos exemplares mais curiosos da loucura fez com que ele dedicasse mais de 30 anos de sua vida ao exame dos 
vagabundos, prostitutas, delirantes e das vítimas de alucinações que vagavam pela Cidade-Luz. Foi entre essa infinita variedade de tipos psicológicos que ele se deparou com as cleptomaníacas que escandalizavam a moral da sociedade vitoriana parisiense por cultivarem um gozo desmedido pelo roubo dos tecidos. Entre elas, encontrou uma paixão que viria a encarnar uma de suas próprias predileções, o caimento e o efeito tátil dos tecidos moles.

Ao longo dos anos, percebe-se gradativamente que Clérambault encorajou-se a escrever textos que demonstravam claramente seu interesse pela tecelagem. Ele redigiu artigos notáveis, tais como Sobre a tecelagem como modo de trabalho para os doentes mentais (1929), Os teares japoneses (1932), Os núcleos inclusos atados e as bainhas fistuladas nos drapeados gregos e Nota sobre o ofício do tecer entre os chineses. Nessa mesma época, animado por sua nova carreira como estudioso dos drapeados, proferiu uma palestra na Sociedade de Etnografia de Paris sobre o tema da Classificação do Drapeado Árabe. Nessa ocasião, a comunidade médica já não via com bons olhos o caminho tomado por Clérambault.

Como médico e artista, Gaetan Gatian de Clérambault denunciou uma divisão que não era muito natural aos médicos de sua época. Era uma figura curiosa, enigmática e excêntrica, como os pacientes que atendia. Sérge Tisseron (1980), no livro A paixão de um neuropsiquiatra pelos tecidos ${ }^{17}$, chegou a se perguntar se a proximidade entrevista por Clérambault entre seus mais íntimos desejos e certas formas de gozo fetichista estudados pela psiquiatria de sua época o deixaram reticente em descrever os casos com os quais se deparava na sua clínica, exatamente por não querer saber sobre a patologia que ligava a paixão de alguns homens com os tecidos e sua própria questão. Talvez por isso havia se contentado em descrever o suposto fetichismo por tecidos apenas nas mulheres, algo que nunca conseguiu sistematizar. Entre suas pacientes, Marie Benjamin ganhou maior destaque e importância, por ser o último caso atendido que reafirmou os outros três com os quais ele já havia se deparado antes dela.

\section{Marie: costureira e louca}

Marie Benjamin tinha 7 anos quando começou a se apaixonar pelas sedas. Foi o que ela disse aos médicos do Asilo Saint-Anne, onde havia sido internada pela primeira vez. Detalhou que "brincava de papai e mamãe, com uma menina, sobre uma cadeira", cuja cobertura era de tecido, quando sentiu um gozo inexplicável (BERLINCK, 2009, p. 278). Essa atração pareceu tê-la arrebatado muito precocemente e, partir daí, passou a se dedicar com frequência à masturbação, solitária ou recíproca, usando pedacinhos da seda. Sobre essa primitiva compulsão, lembrava que se entregava ao onanismo compulsivo, que havia sido deflagrado depois da pitoresca cena com a cadeira. Narrava lembranças muito vivas em relação aos momentos posteriores em que se deparou novamente com o tecido: "Eu me casei para ter um lindo vestido de seda preto, que ficava encorpado. Depois do meu casamento, ainda vestia minhas bonecas; ainda gosto disso. A seda tem um froufrou, um cricri, que me dá prazer" (BERLINCK, 2009, p. 278).

A suposta histérica contava 49 anos no momento em que irrompeu de fato seu sintoma sexual e cleptomaníaco associado à seda. Era tomada de assalto por uma curiosa satisfação que envolvia uma sequência de atos estranhos: furto, exibicionismo e masturbação com o tecido em público. A cena de exibicionismo com a seda denunciava claramente seu ganho secundário, travestido de um apelo muito particular: 0 de ser vista e não somente olhada pelos homens. Era preciso roubar a nesga e dividir com o grande público seu gozo sexual, assim ela se dava a ver. Parecia evidente que essa costureira, nascida na periferia de Paris, demandava, no mínimo, que Clérambault e quem frequentasse as lojas de tecidos olhassem-na sem entender o que a levava a tamanho desregramento. Seu sintoma estava estruturado sobre um cenário e um contexto no qual ela contracenava com a seda.

No prontuário psiquiátrico, Clérambault descreveu que a paciente padecia de uma doença histérica e de uma forma de fetichismo feminino. No relatório clínico, era 
possivel acompanhar suas impressões sobre os sintomas da paciente, que ele descreveu segundo as categorias psicopatológicas de sua época como: delírio de tocar, paixão pela seda, impulsão cleptomaníaca, amoralidade e delinquência banal (BERLINCK, 2009, p. 278). Apesar de sua paixão sexual arrebatadora pela seda, Marie sofria de uma frigidez confessa em relação aos homens. Ela confidenciou aos médicos em uma das entrevistas: "Eu não me importo com os homens, primeiro porque eles se parecem todos" (BERLINCK, 2009, p. 278). Era curioso que ela apresentasse um sintoma de anestesia sexual em relação aos homens, pois com a seda apresentava-se o oposto. Era como se seu verdadeiro par amoroso fosse esse tecido. 0 fato de se exibir também demonstrava que ela talvez tivesse compreendido, como uma boa histérica, a essência do pensamento psiquiátrico de sua época. A escola de psiquitria francesa formada somente por homens foi nomeada de Psiquiatria do Olhar ${ }^{18}$. Era exatamente ao olhar desses homens que Marie se ofertava como objeto para ser admirado.

0 médico que apreciava de perto seus objetos de estudo, para melhor descrevê-los, foi arrebatado pela história da paciente que gostava de ser vista. Tal relação erotizada com a seda, e mesmo com o próprio olhar, tornou-se um dado relevante para a história clínica da paciente e um atrativo à parte para o próprio Clérambault. Essa paixão dirigida ao tecido deixou o psiquiatra muito intrigado. A atração mórbida por esse objeto e o simples fato de ouvir pronunciar a palavra "seda", ou ainda representá-la em pensamento, eram suficientes, dizia ela, para provocar-lhe uma "ereção das partes sexuais" (BERLINCK, 2009, p. 278). 0 orgasmo total se produzia no contato e pela fricção da seda contra a região genital. As qualidades agregadas à seda, como a textura, o frescor e a fineza, eram muito importantes para a paciente.

Para essa costureira a seda do vestido devia possuir, no mais alto grau, a qualidade que ela venerava, a saber, a firmeza: "Eu gosto da seda que fica de pé sozinha" (BERLINCK, 2009, p. 281). 0 tecido não apenas deveria roçar, com delicadeza, a epiderme; mas era preciso ainda que ele tivesse um corpo. Além da maciez superficial, um tipo de energia interna, que lembra o músculo ou qualquer outra tensão parecida com um corpo em trabalho, deveria ser evocada pela seda. Era um fato que Marie procurava na estrutura do tecido da seda um prolongamento do seu próprio corpo. Depois de aposentar as camisas de força espartilhadas, de onde as mulheres de sua época haviam saído recentemente, a seda serviu como uma segunda e pareceu cair ao seu sintoma e a seu corpo como uma luva.

\section{Desdobramentos finais}

Paris entre dois tempos: o final do século XIX, ainda marcado pelo pudor da sociedade francesa vitoriana, refletido nos figurinos modelados por estruturas pesadas e avantajadas, encerrando o corpo feminino numa verdadeira fortaleza. 0 novo tempo de Paris do início do século $X X$, tomada pelas inovações na arte, na ciência, na psiquiatria e, sobretudo, no corte simples e leve dos mais novos trajes femininos confeccionados com tecidos finos e leves, caindo suavemente, como uma luva, sobre o corpo das mulheres e sobre a fantasia de alguns homens.

Marie Benjamim, uma paciente psiquiátrica vítima escandalosa de um mal que respondia também pelo nome de "vício" ou "delito". Uma transeunte que vagava pela cidade à procura de tecidos e que nutria impulsos estranhos pela seda. Uma mulher que viveu à sua maneira as inquietações de sua época, que testemunhou a migração dos véus que confeccionava para suas clientes na tarefa caseira de "trançar e tecer" para as deslumbrantes feiras de Moda de Paris daqueles anos. Nesse mesmo momento, a mulher recatada, arrebatada por um escandaloso sintoma, acometida por uma paixão irrefreada por sedas, passou a roubar o que era o tecido-símbolo do luxo e da elegância. Transformou-se, depois de passar pelo crivo do Dr. Clérambault, numa personagem de prontuários psiquiátricos, artigos de antropologia criminal e ainda, de filme e livro sobre as curiosidades eróticas do início do século.

0 médico, Gaetan Gatian de Clérambault, artista e cientista, que viveu sob a sombra do olhar frio e austero que a psiquiatria da época lançava sobre a loucura e o excesso feminino, tempo em que a ciência interrogava brutalmente a sexualidade dos loucos e principalmente das mulheres. Foi testemunha de um tempo em que se entregar às obsessões, pequenas manias ou vícios extravagantes, coincidia com um 
prazer afrontoso e duramente questionado, por se tratar de um vício egoísta e uma recusa ao laço com o outro ${ }^{19}$.

A seda, tecido flexível, leve e fino, que contornava o incontornável, dando corpo e pele a cada uma das mulheres recém-saídas de uma armadura de tecidos brocados e armados da época clássica das cortes europeias. Fino e eletrizante fio, talismã do tempo da Belle Époque francesa, paixão natural das mulheres que se ocuparam em recriar uma nova imagem para si mesmas. Além disso, na língua francesa, soie, seda, faz homofonia com dois outros termos desta língua: soit e soi, respectivamente, "seja" e "si". Nas entrelinhas, pode-se ouvir "soi même", "si mesma", e "soit", "seja", verbo ser/existir, no subjuntivo. Tratava-se de fato de criar, de fazer existir de alguma forma, numa sociedade em que as mulheres não tinham muito como existir, uma nova mulher que tomasse seu corpo para si mesma. A seda vestiu com palavras a mulher do novo século. Nos símbolos e signos da língua francesa e nas camadas drapeadas dos vestidos de seda, uma nova versão da feminilidade poderia verdadeiramente existir.

Marie Benjamin e Gaetan Gatian de Clérambault foram personagens complexos que surgiram no desdobrar do século XIX para o século XX, no momento em que a divisão ética e estética que a sociedade vivia passou a ilustrar-se na vida particular de cada um dos homens e mulheres daquele tempo. Figuras que outrora eram apenas entrevistas pelas frestas do pudor de uma época provinciana, tiveram que avançar e tomar a palavra para fazer a difícil confissão daquilo que realmente eram. Marie confessou através de seu sintoma, e Clérambault sublimou suas paixões através de seus estudos sobre a arte dos tecidos.

Marie gozou do privilégio de poder ir às ruas lançar o enigma de seu sintoma a todos que quisessem olhar. Clérambault não teve a mesma sorte, pois era um doutor famoso e tinha que manter a pose, transcendendo o seu também irremediável desejo pelos tecidos de forma mais velada e talvez até mesmo mais feminina. Entretanto, um sintoma recalcado durante muito tempo por esse médico alienista fez sua irrupção na forma de um ato abrupto: o suicídio. Esse médico de olhar clínico sofria de sérios transtornos visuais, que progrediram até a cegueira completa. Logo, ao se perceber sem os benefícios de seu melhor sentido, cego, matou-se diante de um espelho, com seu revólver de oficial da Primeira Guerra Mundial ${ }^{20}$. Ao leitor arguto, para além dessa cena anunciada pelos jornais sensacionalistas da época, não é difícil perceber nas entrelinhas a profunda e comovente identificação de Clérambault com a paixão que suas pacientes vertiam pela seda. 0 espelho no qual ele não podia se ver refletia a imagem delas.

A vida desse neuropsiquiatra francês chegou ao fim, deixando aos que sobreviveram a ele seu derradeiro enigma. Aqueles que foram buscar por vestígios que pudessem explicar sua morte trágica encontraram, entre seus pertences, uma lápide que ele mesmo encomendara em Fez, no Marrocos, vinte anos antes de morrer. Lá havia cravada uma mensagem que contradizia o seu último ato: suicidar-se, cego, em frente a um espelho, símbolo maior da vaidade, olhando-se pela última vez, sem mesmo poder se ver. Na pedra que mandou esculpir para colocar em seu túmulo, um provérbio árabe previne os homens desavisados que não se esqueçam de que a morte abate a todos, até os mais vaidosos:

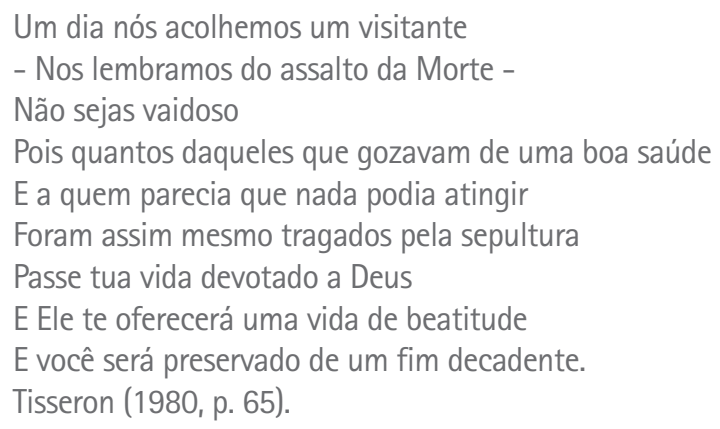




\section{NOTAS}

[1] À Stella, minha "dernière Mode".

${ }^{[2]}$ No filme Le crie de la soie, a paciente foi chamada de Marie Benjamin, entretanto, nos prontuários, seu médico psiquiatra a nomeia de Marie D.

[3] Le crie de la soie, filme de Yvon Marciano produzido na França em 1996. 0 "grito da seda" é uma expressão que foi pinçada do interior do texto de Gaetan Gatian de Clérambault para descrever as sensações táteis de sua paciente Marie em relação a seda.

${ }^{4]} 0$ texto A paixão erótica das mulheres pelos tecidos foi publicado nos Arquivos de Antropologia Criminal do ano de 1908.

${ }^{5]}$ Femme coment il fautfoi o termo com o qual Honoré de Balzac descreveu as mulheres francesas do século XIX no livro Estudos de mulher.

${ }^{[6]}$ Selling (2000). A expressão "costureira de corte simples" foi criada no século XIX pelo discurso próprio da moda para distinguir a diferença entre os costureiros homens, os couturiers, e as mulheres que se ocupavam das costuras somente em casa.

[7] Clérambault era um dos membros da chamada Escola Francesa do entreguerras. Ele integrava um grupo de psiquiatras que estavam produzindo as bases epistemológicas da chamada Psiquiatria do Olhar, cuja essência de sua prática era a análise do quadro clínico, a partir da observação do paciente e da descrição de seus sintomas e sinais.

${ }^{[8]}$ Selling (2000) descreve a Exposição Mundial de Moda onde aconteceu 0 Pavillon de l'Élegance, como um evento de moda inaugural em Paris.

[9] Em 1858, o estilista Charles Frederick Worth produziu os primeiros desfiles de moda com manequins de "carne esso", substituindo os cabides.

${ }^{10]} 0$ vestido La vaguefoi detalhado por Selling (2000) como um modelo de roupa que deixava o corpo feminino livre.

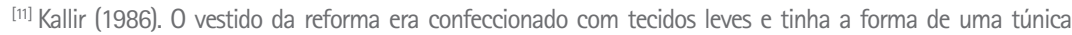
solta. Sua silhueta era propositalmente desprovida de curvas e não havia nenhum tipo de ornamentação a que estavam habituadas as mulheres do século XIX

${ }^{[12]}$ De acordo com Selling (2000), alta-costura foi uma expressão criada no século XX, quando a moda como fenômeno tem seu início.

${ }^{[13]}$ Selling (2000) esclarece que os couturiers são os costureiros de moda.

${ }^{[14]}$ Os fundamentos da clínica.

[15] 0 automatismo mental foi uma síndrome descrita por Clérambault e consistia numa série de delírios interpretativos do paciente, com sentimentos de estranheza do próprio eu e das coisas, negação sistemática de fatos importantes, como a morte de alguém, e intuições, imaginações e sensações de déjả vu.

${ }^{[16]}$ A erotomania pura foi também descrita como uma síndrome, mais especificamente um delírio amoroso, cuja característica principal era o desejo esperançoso de ser correspondido por uma pessoa desconhecida associada a um delírio reivindicatório e ciumento, que foi denominado de "estado passional mórbido". 0 conjunto de sintomas dessa doença, nomeada de Síndrome de Clérambault, foi traçado no filme A la folie, pas du tout(2002)

[17] Nooriginal, em francês, Passionérotiquedêsétoffeschezumneuropsichiatre.

[18] Segundo o livro Os fundamentos da clínica, de Paul Bercherie (1989), a psiquiatria nessa época vivia a chamada "clinica do olhar".

[19] 0 chamado "vício solitário", ou tecnicamente nomeado de onanismo, era a fonte de grave adoecimento psíquico, segundo a psiquiatria da época.

${ }^{20]}$ Os jornais da época contam que Clérambault se matou dessa forma.

\section{REFERÊNCIAS}

BAIZAC, Honoré. Estudos de mulher. Porto Alegre: L\&PM, 2006. BERCHERIE, Paul. Os fundamentos da clínica: história e estrutura do saber psiquiátrico. Rio de Janeiro: Jorge Zahar, 1989

BERCHERIE, Paul. Os fundamentos da clínica: história e estrutura do saber psiquiátrico. Rio de Janeiro: Jorge Zahar, 1989.

BERLINCK, Manoel Tosta. Erotomania. São Paulo: Escuta, 2009

CLÉRAMBAULT, Gaetan Gatian de. Passion érotique dês étoffes chez la femme. Paris: Le Seuil, 2003.

KALLIR, Jane. Viennese Design and the Wienner Werkstätte. New York: Galerie St. Ettienne/George Braziller, 1986

SELLING, Charlotte. Moda do século XX. São Paulo: Könemann, 2000.

TISSERON, Sérge. La passion dês etoffes chez um neuro-psychiatre. Paris: Solin, 1980 